\title{
Dipterocarpus Gaertn. (Dipterocarpaceae) leaf from the Middle Siwalik of eastern Nepal and its phytogeographic and climatic significance
}

\author{
"Gaurav Srivastava1, Purushottam Adhikari', Rakesh C. Mehrotra', Lalu Paudel ${ }^{2}$, Dieter Uhl ${ }^{3}$, and Khum N. Paudayal ${ }^{2}$ \\ ${ }^{1}$ Birbal Sahni Institute of Palaeosciences, Lucknow, India \\ ${ }^{2}$ Central Department of Geology, Tribhuvan University, Kirtipur, Kathmandu, Nepal \\ ${ }^{3}$ Senckenberg Forschungsinstitut und Naturmuseum, Senckenberganlage 25, 60325 Frankfurt am Main, Germany \\ *(Corresponding email: gaurav_jan10@yahoo.co.in)
}

\begin{abstract}
A leaf of Dipterocarpus (Dipterocarpaceae) is described from the Lower member of Middle Siwalik of eastern Nepal. Its presence indicates that during the deposition of the sediments there was a warm and humid climate with dry season of not more than 3-4 months. The modern distribution of the genus and family reveals that nowadays they have disappeared from the modern flora of Nepal. The most plausible reason for their disappearance might be an increase in length of the dry season caused by the upliftment of the Himalaya.
\end{abstract}

Key words: Fossil, climate change, Dipterocarpaceae, Miocene, Nepal

Received: 19 March 2017

Revision accepted: 15 June 2017

\section{INTRODUCTION}

Dipterocarpaceae is an important family because of its economical and ecological significance. It encompasses three subfamilies having intercontinental distribution such as Dipterocarpoideae in Asia, Pakaraimoideae in South America, and Monotoideae in Africa and South America (Dayanandan et al. 1999). The molecular phylogenetic analysis reveals that the family has a Malvalean affinity (Dayanandan et al. 1999). It comprises 17 genera and 535 species which are all arboreal and distributed in the tropics (Mabberley 2008). The genus Dipterocarpus Gaertn. belongs to Dipterocarpoideae and envelops 70 species distributed in India, Sri Lanka, Myanmar, Thailand, Indo-China, Yunnan, Malaya, Sumatra, Java, Bali, Borneo and Philippines (Mabberley 2008). The fossil record of the genus is well represented in the form of wood (Srivastava et al. 2014 and references there in), leaves (Prasad 2008) and pollen (Muller 1981; Songtham et al. 2005; Rugmai et al. 2008), however its fruits are very rare (Grote 2007). In the present communication, we report a fossil leaf impression of Dipterocarpus from the Siwalik sediments of eastern Nepal (Fig. 1). We also discuss the phytogeographical implications based on the fossil records of the family Dipterocarpaceae and the genus Dipterocarpus.

\section{GEOLOGY OF THE STUDY AREA}

The rocks belonging to the Siwalik Group are well exposed in the Sapta Koshi River and along Chatara to Barahakshetra road section (Fig. 2). Good exposures can also be found along the Rani Khola, Dhansar Khola, Dudhpani Khola, Kosopa Khola, Bahune Khola, Kokaha Khola, and Bramanand Khola. The rocks of the study area can mainly be divided into two litho-stratigraphic units, namely the Lower Siwalik and the Middle Siwalik. On the basis of lithology, texture, and grain size variation both Lower and Middle Siwalik can further be divided into Lower and Upper Members. The Upper Siwalik is missing from the study area (Fig. 2). The Siwalik is separated by Main Boundary Thrust (MBT) with the Lesser Himalayan Precambrian dolomite sequences and Gondwana sediments in the north (Bashyal 1980; Dhital 2015).

\section{Lower Siwalik}

It is composed of mudstone, sandstone and siltstone. The sequences of variegated mudstone beds are bluish grey, greenish grey, purple, yellowish grey, grey and black in colour. The thickness of mudstone beds ranges from 20 to $480 \mathrm{~cm}$, but the thickness of sandstone beds is lesser than mudstone. Bioturbation, and concretions are found in mudstone beds. The siltstone beds are dark grey, bluish grey, greenish grey and purple ranging 20 to $200 \mathrm{~cm}$ in thickness. The variegated mudstone and siltstone are very fine to fine grained and light grey, greenish grey to dark grey in colour with 15 to $260 \mathrm{~cm}$ in thickness. However, at some places sandstone is medium grained, dark grey in colour and up to $42 \mathrm{~cm}$ in thickness. The mudstone, siltstone and sandstone show the presence of calcareous cement. The plant fossils are found in lower and upper parts of this lithounit. The contact between Lower and Upper Members is transitional. In the Upper Member the thickness of sandstone beds is more than that of mudstone beds.

\section{Middle Siwalik}

This litho unit consists of medium to coarse grained 'salt and 


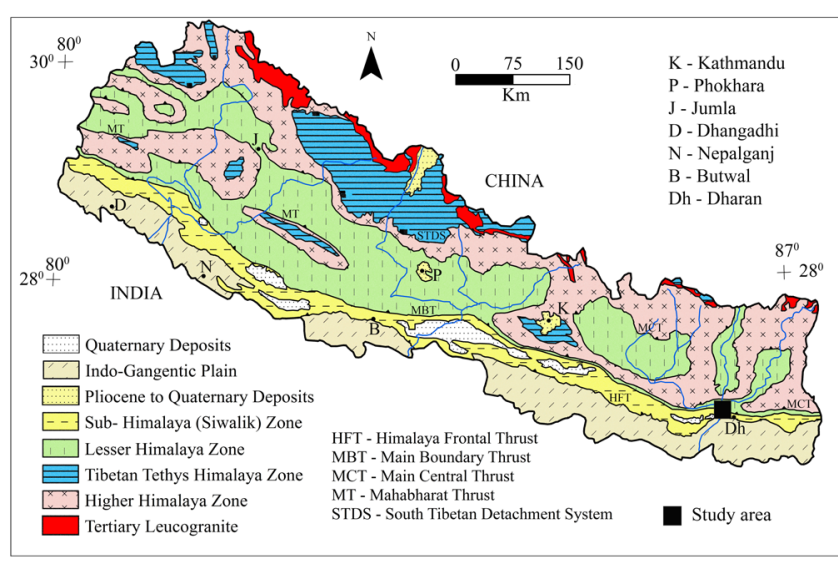

Fig. 1: Distribution of Siwalik sediments in Nepal (black square indicates study area). pepper' textured sandstone and fine grained, light grey up to $220 \mathrm{~cm}$ thick sandstone beds. The thickness of sandstone beds is up to $12 \mathrm{~m}$. Dark grey, up to $200 \mathrm{~cm}$ thick mudstone is found. The plant fossils are found in mudstone and siltstone. The calcareous cement is profusely present in mudstone, siltstone, and sandstone beds. The contact between the Upper Member of Lower Siwalik and the Lower Member of Middle Siwalik is transitional. It consists of thickly bedded, coarse grained to very coarse grained, 'salt and pepper' textured sandstone, pebbly sandstone with fine grained sandstone, siltstone, and mudstone.

Leaf bearing horizons are found in the Lower Member of Middle Siwalik near Chatara (Fig. 2, location F1), Lower and Upper Members of Middle Siwalik near Bahune Khola, Satra Number and Bramananda Khola (Fig. 2, location F2, F3, F4, F5 and F6). The Dipterocarpus leaf locality lies in F2 location (Fig. 2) and its lithological details are shown in Fig. 3.

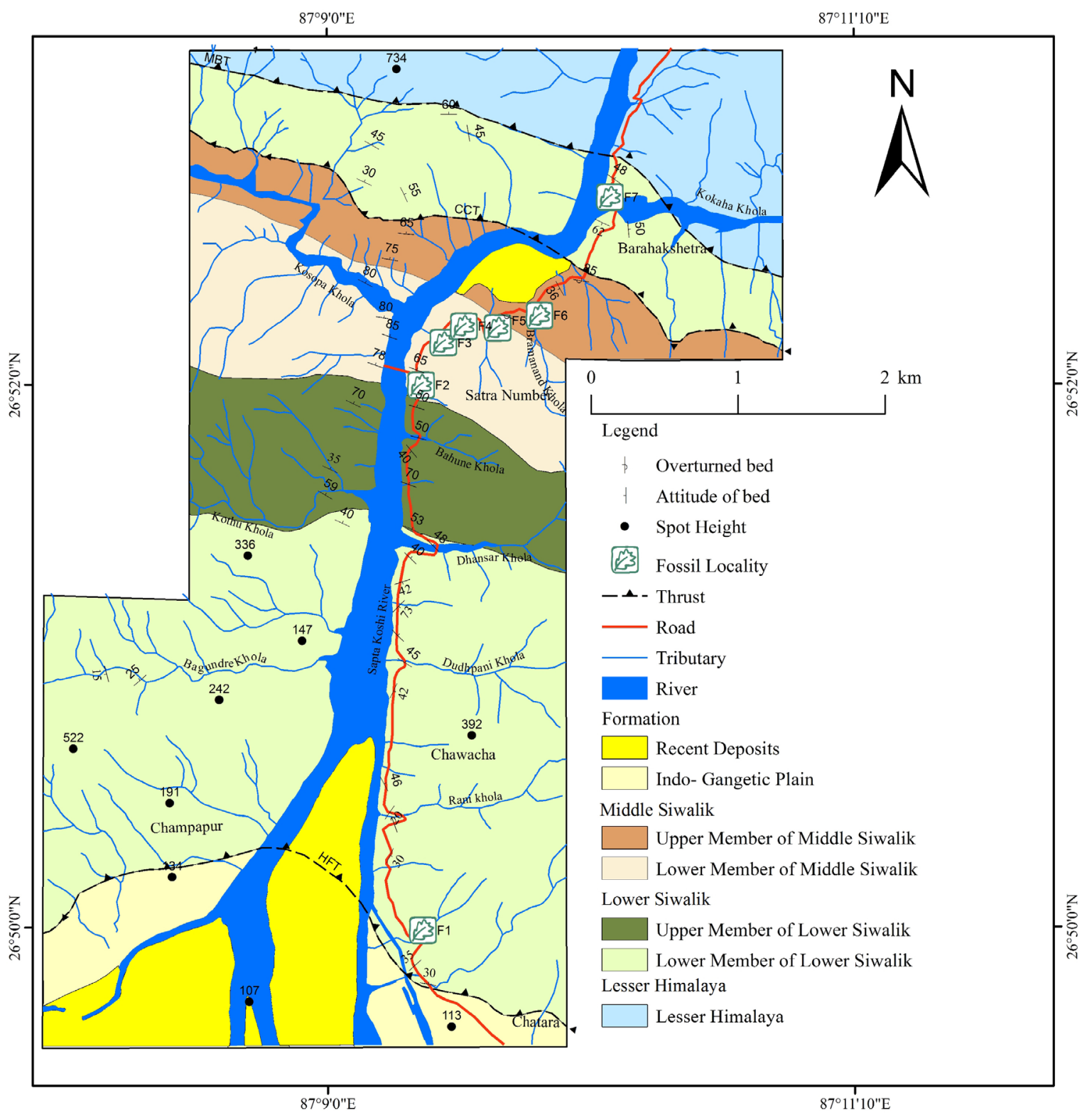

Fig. 2: Geological map of the studied area showing the fossil locality. 


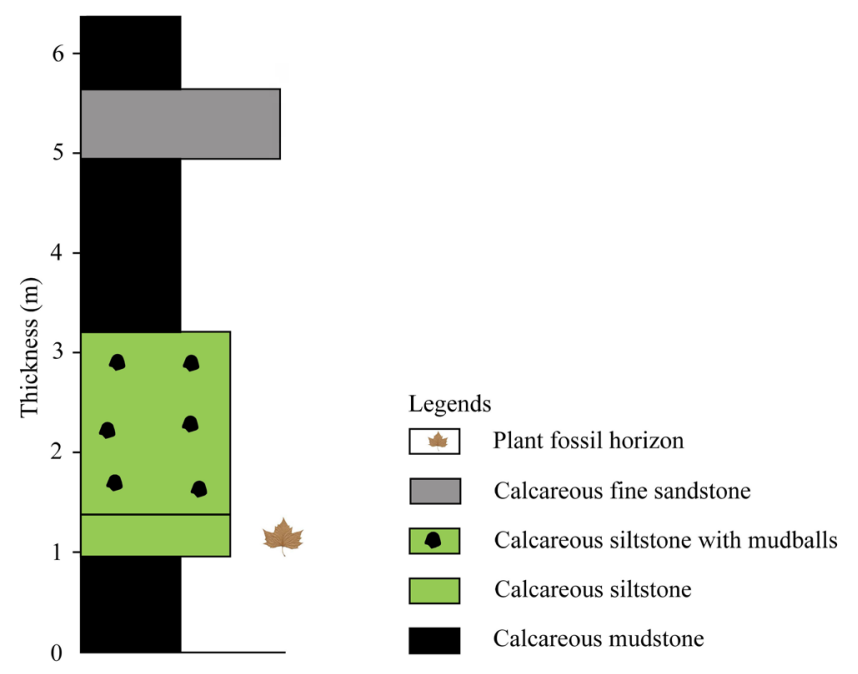

Fig. 3: Lithological details of the Dipterocarpus horizon at F2 location.

\section{MATERIAL AND METHODS}

The present fossil leaf was collected by one of us (PA) during a field excursion from the Middle Siwalik sediments of eastern Nepal (Fig. 1). The fossil leaf was cleared with the help of chisel and hammer and photographed under the natural light with the help of digital Camera SX110. The terminology proposed by Dilcher (1974) and Ellis et al. (2009) was followed in describing the present fossil. The fossil leaf was identified at the Central National Herbarium (CNH), Howrah. All the fossil specimens are deposited in the museum of Central Department of Geology, Tribhuvan University, Kirtipur, Kathmandu, Nepal.

\section{RESULTS}

\section{Systematics}

Order: Malvales

Family: Dipterocarpaceae

Genus: Dipterocarpus Gaertn.

Species: Dipterocarpus sp. (Pl. I, Figs 1-4; Pl. II, Fig. 4)

Figured specimen nos.: 17N20ii, 17N10B, 17N9C

Locality: F2, Satra Number

Horizon and age: Middle Siwalik; Middle Miocene

\section{Description}

Leaf incomplete, mesophyll, elliptic; maximum preserved lamina length 7.6-13.8 cm, maximum preserved lamina width 5.5-14.4 cm; apex not preserved; base not preserved; margin entire; texture coriaceous; petiole not preserved; venation eucamptodromous; primary vein thickness $\sim 0.14$ $\mathrm{cm}$, straight; secondary veins 8 pairs visible, distance between two secondary veins $0.5-1.5 \mathrm{~cm}$, not uniform, alternate to sub-opposite, angle of divergence very narrow to moderate acute $\left(23^{\circ}-63^{\circ}\right)$, nearly straight and abruptly turned up near the margin joining superadjacent secondary veins with tertiary veins; intersecondary veins absent; tertiary veins simple and forked percurrent and recurved, oblique in relation to midvein; quaternary veins percurrent; areoles well developed, predominantly quadrangular.

\section{Affinities}

The remarkable features of the fossil leaf such as mesophyll size, coriaceous texture, pinnate eucamptodromous venation, narrow to moderate acute angle of divergence of secondary veins, abruptly curved secondary veins near the margin, absence of intersecondary veins and percurrent tertiary veins indicate its affinity with the modern leaves of Dipterocarpus (Pl. II, Figs. 1-3) of the family Dipterocarpaceae. Several herbarium specimens of the modern genus were studied in detail but due to incompleteness of the fossil it is difficult to identify it up to the specific level.

Fossil leaves of Dipterocarpus have been reported from the Cenozoic sediments of India and abroad. Heer (1883) reported Dipterocarpus antiques and D. atavinus from the Tertiary sediments of Sumatra, while Geyler (1887) reported D. tabuanus and D. nordenskioldi from the Pliocene of Java. Several fossil leaves of the genus have been described from the Siwalik sediments of India, Nepal and Bhutan (Lakhanpal and Guleria 1987; Prasad 1990; 1994; Awasthi and Prasad 1990; Antal and Prasad 1996; Prasad and Pradhan 1998; Prasad et al. 1999; Guleria et al. 2000; Prasad and Tripathi 2000; Prasad and Pandey 2008; Khan et al. 2011; Prasad et al. 2017).

\section{DISCUSSION}

\section{Palaeoclimatic implications of Dipterocarpus}

The distributions of plants are strongly governed by their corresponding climatic conditions (Woodward et al. 2004). For palaeoclimate reconstruction we have chosen the Nearest Living Relative (NLR) method. The NLR method implies that the modern analogs of the fossils are still living in the same climatic conditions as in the past and no significant change has taken place in environmental requirements of the taxon (MacGinitie 1941; Hickey 1977; Chaloneer and Creber 1990; Mosbrugger 1999). The modern distribution of Dipterocarpus has been investigated and its climatic tolerance was recorded (Table 1).

The climatic range of Dipterocarpus indicates that it requires mean annual temperature (MAT) of $24-28.1{ }^{\circ} \mathrm{C}$, warmest month mean temperatures (WMMT) of $26.5-30.1{ }^{\circ} \mathrm{C}$, cold month mean temperatures (CMMT) of $16.4-26.3^{\circ} \mathrm{C}$ and mean annual precipitation (MAP) of 1438-4172 mm (Table 1). The climate range of the NLR indicates that during the deposition of the sediments the fossil locality experienced a warm and humid climate with plenty of rainfall. It also indicates that the length of the dry season was not more than 3-4 months (Champian and Seth 1968). However, nowadays the genus is not found in the entire flora of Nepal (Press et al. 2000). The most plausible reason for its disappearance from the modern flora of Nepal might be an increase in length of the dry season i.e. aridity caused by the upliftment of the Himalaya during the late Neogene (Valdiya 2002). 

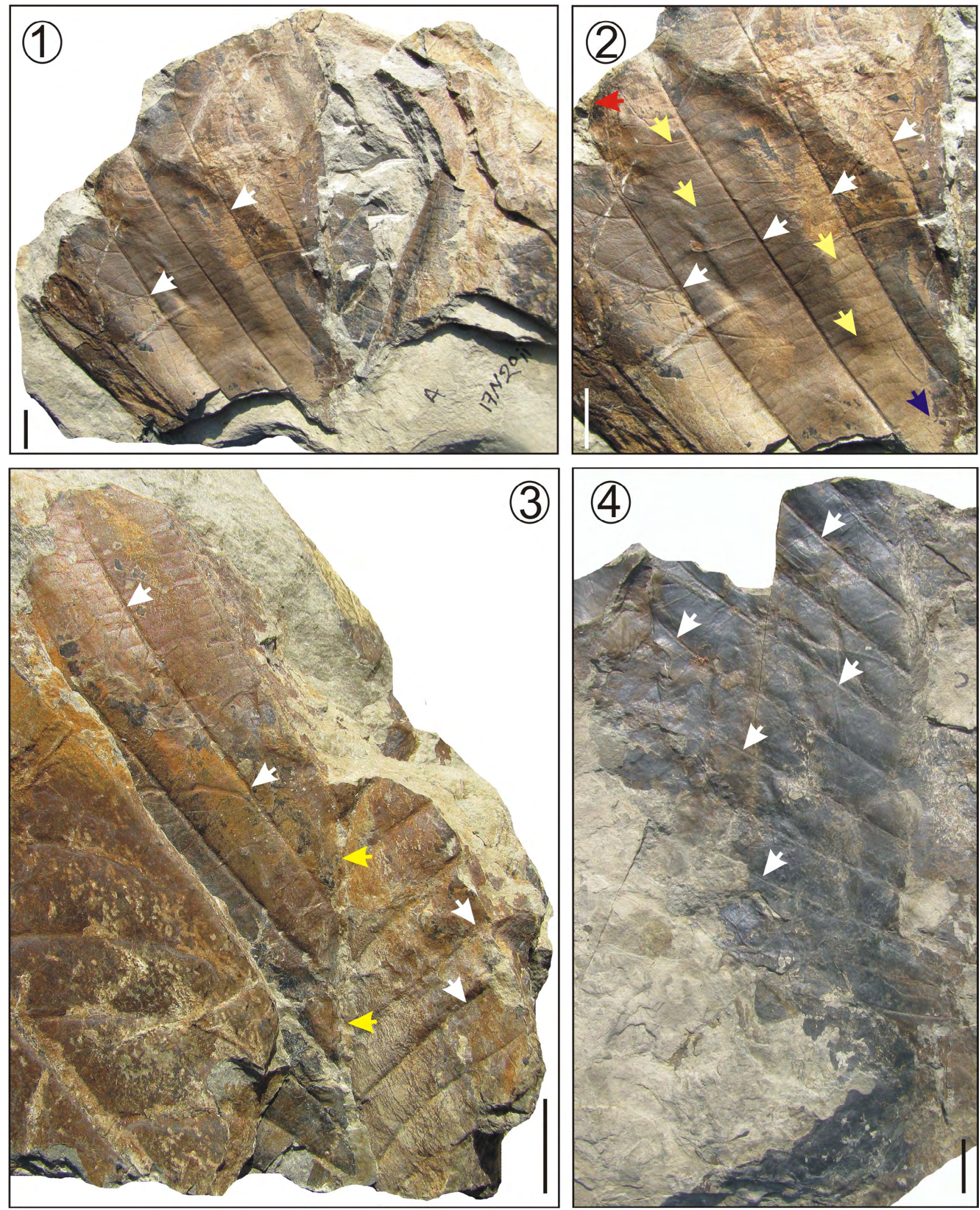

Plate I: Fossil leaves of Dipterocarpus: Fig. 1. Fossil leaf showing shape, size and secondary veins (white arrows) (17N20iiA), 2. Enlarged portion of the fossil leaf (17N20iiA) showing secondary veins (white arrows), percurrent (yellow arrows) and recurved (blue arrow) tertiary veins and curving up of secondary veins near the margin (red arrow), 3 . Another specimen of the fossil leaf (17N10B) showing primary vein (yellow arrows) and secondary veins (white arrows), 4 . Fossil leaf (17N9C) showing secondary veins (white arrows). All bar scales $=1 \mathrm{~cm}$. 

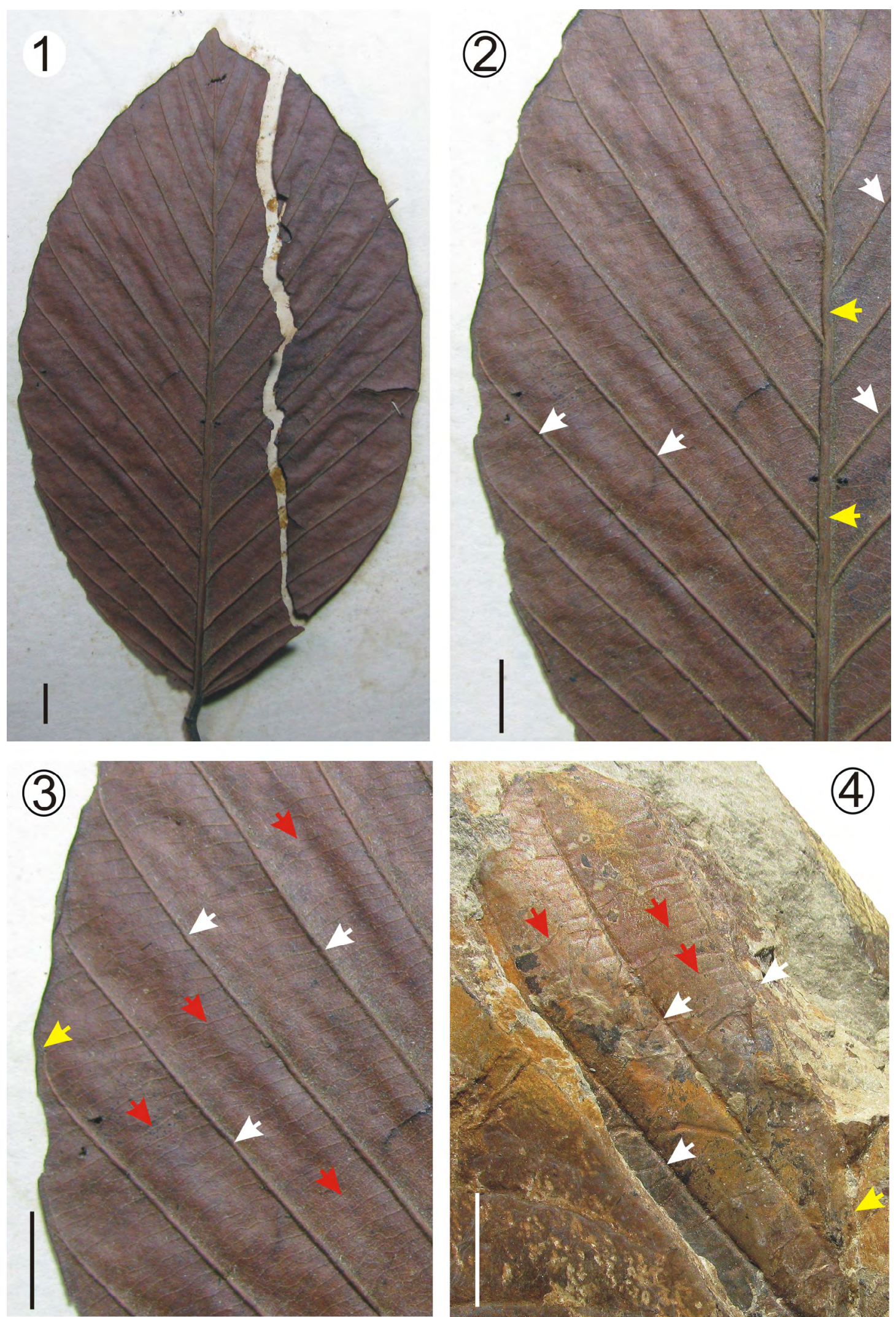

Plate II: Leaves of Dipterocarpus: Fig. 1. Modern leaf of Dipterocarpus gracilis Blume showing shape, size and venation pattern (CNH herbarium sheet no. 63061), 2. Enlarged portion of the modern leaf of $D$. gracillis showing primary vein (yellow arrows) and secondary veins (white arrows), 3 . The modern leaf showing secondary veins (white arrows), their curving up near the margin (yellow arrow) and percurrent tertiary veins (red arrows), 4. Enlarged portion of the fossil leaf (17N10B) showing similar primary (yellow arrow), secondary (white arrows) and tertiary veins (red arrows). All bar scales $=1 \mathrm{~cm}$. 
Table 1. Climatic tolerance of extant Dipterocarpus in modern forest localities (after Shi and Li 2010).

\begin{tabular}{|l|l|l|l|l|l|}
\hline Localities & Cordinates & MAT $\left({ }^{\circ} \mathbf{C}\right)$ & WMMT $\left({ }^{\circ} \mathbf{C}\right)$ & CMMT $\left({ }^{\circ} \mathbf{C}\right)$ & MAP $(\mathbf{m m})$ \\
\hline Trivandrum, India & $8.48^{\circ} \mathrm{N}, 79.95^{\circ} \mathrm{E}$ & 26.6 & 28.3 & 25.6 & 1696 \\
\hline Colombo, Sri Lanka & $6.9^{\circ} \mathrm{N}, 79.87^{\circ} \mathrm{E}$ & 26.9 & 28.1 & 25.9 & 2345 \\
\hline Tezpur, Assam, India & $26.6^{\circ} \mathrm{N}, 92.78^{\circ} \mathrm{E}$ & 24 & 28.6 & 17.2 & 1882 \\
\hline Bhamo, Myanmar & $24.27^{\circ} \mathrm{N}, 97.28^{\circ} \mathrm{E}$ & 24.2 & 28.3 & 16.4 & 1857 \\
\hline Bangkok, Thailand & $13.75^{\circ} \mathrm{N}, 100.47^{\circ} \mathrm{E}$ & 28.1 & 30.1 & 25.7 & 1438 \\
\hline Hanoi, Vietnam & $21.03^{\circ} \mathrm{N}, 102.87^{\circ} \mathrm{E}$ & 24 & 29.4 & 16.7 & 1682 \\
\hline Ho Chi Minh City, Vietnam & $10.78^{\circ} \mathrm{N}, 106.7^{\circ} \mathrm{E}$ & 27.6 & 30 & 26.1 & 1985 \\
\hline Kuala Terengganu, Malaysia & $5.33^{\circ} \mathrm{N}, 103.13^{\circ} \mathrm{E}$ & 26.6 & 27.8 & 25.3 & 25 \\
\hline Padang, Sumatra, Indonesia & $0.93^{\circ} \mathrm{N}, 110.37^{\circ} \mathrm{E}$ & 26.6 & 27.5 & 25 & 4172 \\
\hline Surakarta, Java, Indonesia & $7.75^{\circ} \mathrm{S}, 110.6^{\circ} \mathrm{E}$ & 25.9 & 26.5 & 25.9 & 1848 \\
\hline Kuching, Borneo, Malaysia & $1.48^{\circ} \mathrm{N}, 110.33^{\circ} \mathrm{E}$ & 27 & 27.8 & 26.3 & 3905 \\
\hline Davao, Mindanao, Philippines & $7.06^{\circ} \mathrm{N}, 125.6^{\circ} \mathrm{E}$ & 27 & 27.7 & $\mathbf{1 6 . 4 - 2 6 . 3}$ & 1930 \\
\hline Climatic range & & $\mathbf{2 4 - 2 8 . 1}$ & $\mathbf{2 6 . 5 - 3 0 . 1}$ & $1438-4172$ \\
\hline Fossil locality & & 21.8 & 26.1 & 1546 \\
\hline
\end{tabular}

MAT $=$ Mean Annual Temperatures

WMMT $=$ Mean Temperatures of the Warmest Month

$\mathrm{CMMT}=$ Mean Temperatures of the Coldest Month

$\mathrm{MAP}=$ Mean Annual Precipitation

\section{Origin and phytogeography of Dipterocarpaceae}

The origin of Dipterocarpaceae is still a matter of debate and two hypotheses have been proposed. The first hypothesis favours its origin in southeast Asia, while the other advocates its origin in Gondwanaland. The former gets strong support from the megafossils recorded from the Paleogene sediments (Bande and Prakash 1985; Feng et al. 2013) and high diversity of the family in southeast Asia (Mabberley 2008). However, some Paleogene fossils of the family in the form of pollen and wood have also been reported from India (Rust et al. 2010; Dutta et al. 2011) but they are questionable (Shukla et al. 2013). The abundance of authentic megafossil records from the Paleogene sediments of southeast Asia (Bande and Prakash 1985; Feng et al. 2013) and Neogene megafossil records from the Indian sub-continent indicates that the family might be immigrated to India after the collision of the Indian Plate with the Eurasian Plate (Srivastava and Mehrotra 2010). However, the aforesaid hypothesis can't explain the modern distribution of Dipterocarpaceae in Gondwanaland continents such as South America, Africa, Madagascar and Seychelles as their seeds are devoid of dormancy and lack salt tolerance and hence can not travel long distance by sea or in arid climates (Ashton 1982; Shi and Li 2010). The second hypothesis suggests that the family probably originated in Gondwanaland during the Late Cretaceous in rain forests of Africa or South America before their separation (Morley 2000). Morley (2000) also suggested that the family expanded widespread during the warm phase of the Paleogene. However, the second hypothesis lacks reliable megafossil records from the Paleogene sediments of Gondwanaland (Shukla et al. 2013). In view of the aforesaid discussion it seems that more reliable fossil records are needed either from the Gondwanaland or from southeast Asia to make a clear picture for the origin and dispersal of Dipterocarpaceae.

\section{ACKNOWLEDGEMENTS}

GS and RCM are thankful to the Director, Birbal Sahni Institute of Palaeosciences for providing necessary facilities for research work. They are also thankful to the Director, Central National Herbarium, Howrah for permission to access its herbarium. The master thesis grant to PA from Chinese Academy of Sciences, Beijing is gratefully acknowledged. We would also like to thank Drona Adhikari and Keshav Shrestha for their help in field work.

\section{REFERENCES}

Antal, J. S., and Prasad, M., 1996, Dipterocarpaceous fossil leaves from Ghish River section in Himalayan foot hills near Oodlabari, Darjeeling District, West Bengal. Palaeobotanist, v. 43, pp. 73-77.

Ashton , P. S., 1982, Dipterocarpaceae. In van Steenis C. G. G. J. (Ed.): Flora Malesiana, series 1, Spermatophyta, MartinusNijhoff Publications, The Hague, Netherlands. v. 9, pp. 237552.

Awasthi, N., and Prasad, M., 1990, Siwalik plant fossils from Surai Khola area, western Nepal. Palaeobotanist, v. 44, pp. 298-318.

Bande, M. B., and Prakash, U., 1986, The Tertiary flora of Southeast Asia with remarks on its palaeoenvironment and phytogeography of the Indo-Malayan region. Rev. Palaeobot. Palynol., v. 49, pp. 203-233.

Bashyal, R. P., 1980, Gondwana type of formation with phosphatic rocks in S. E. Nepal. Jour. Geol. Soc. India, v. 21, pp. 489-491.

Chaloner, W. G. and Creber, G. T., 1990, Do fossil plants give a climatic signal? Jour. Geol. Soc. London, v. 147, pp. 343-350.

Dayanandan, S., Ashton, P. S., Williams, S. M., and Primack, R. B., 1999, Phylogeny of the tropical tree family Dipterocarpaceae based on nucleotide sequences of the chloroplast RBCL gene. Am. Jour. Bot., v. 86(8), pp. 1182-1190.

Dhital, M. R., 2015, Geology of the Nepal Himalaya: Regional Perspective of the Classic colloidal origin. Springer, $499 \mathrm{p}$. 
Dilcher, D. L., 1974, Approaches to the identification of angiosperm leaf remains. Bot. Rev., v. 40, pp. 1-157.

Dutta, S., Tripathi, S. M., Mallik, M., Mathews, R. P., Greenwood, P. F., Malagalapalli, R. R., and Summons, E., 2011, Eocene out-of-India dispersal of Asian dipterocarps. Rev. Palaeobot. Palynol., v. 116, pp. 63-68.

Ellis, B., Daly, D., Hickey, L. J., Johnson, K. R., Mitchell, J., Wilf, P., and Wing, S. L., 2009, Manual of Leaf Architecture. Cornell University Press, New York, 190 p.

Feng, X., Tang, B., Kodrul, T. M., and Jin, J., 2013, Winged fruits and associated leaves of Shorea (Dipterocarpaceae) from the late Eocene of south China and their phytogeographic and paleoclimatic implications. Am. Jour. Bot., v. 100(3), pp. 574581.

Geyler, H. T. H., 1887, Uber fossile Pflanzen von Labuan. Vega Exped. Vetensk Arbeten, v. 4, pp. 475-507.

Grote, P. J., 2007, Studies of fruits and seeds from the Pleistocene of northeastern Thailand. Cour. Forschungsinst. Senckenb., v. 258, pp. 171-181.

Guleria, J. S., Srivastava, R., and Prasad, M., 2000, Some fossil leaves from the Kasauli Formation of Himachal Pradesh, North-west India. Himal. Geol., v. 21, pp. 43-52.

Heer, O., 1883, Beitrage Zur fossilen flora von Sumatra.- Denkschr. Schweiz Ges. Gas. Naturwiss, v. 28, pp. 1-22.

Hickey, L. J., 1977, Stratigraphy and paleobotany of the Golden Valley Formation (early Tertiary) of western north Dakota. Geol. Soc. Am. Mem., v. 150, pp. 1-183.

Khan, M. A., Ghosh, R., Bera, S., Spicer, R. A. and Spicer, T. E. V., 2011, Floral diversity during Plio-Pleistocene Siwalik sedimentation (Kimin Formation) in Arunachal Pradesh, India, and its palaeoclimatic significance. Palaeobiodivers. Palaeoenvironments, v. 91, pp. 237-255.

Lakhanpal, R. N., and Guleria, J. S., 1987, Fossil leaves of Dipterocarpus from the Lower Siwalik beds near Jawalamukhi, Himachal Pradesh. Palaeobotanist, v. 35, pp. 258-262.

Mabberley, D. J., 2008, The Plant Book II. A Portable Dictionary of Vascular Plants. Cambridge University Press, UK. 1021 p.

MacGinitie, H. D., 1941, A middle Eocene flora from the central Sierra Nevada. Carnegie Inst. Wash. Publ., Washington, v. 534, pp. 1-94.

Morley, R. J., 2000, Origin and evolution of tropical rain forests. John Wiley and Sons, Chichester, UK. 378 p.

Mosbrugger, V., 1999, The nearest living relative method. In: Jones T. P. and Rowe N. P., (Eds.): Fossil plants and spores modern techniques. Geol. Soc., London, pp. 261-265.

Muller, J., 1981, Fossil pollen records of extant angiosperms. Bot. Rev., v. 47(1), pp. 1-142.

Prasad, M., 1990, Fossil flora from the Siwalik sediments beds of Himachal Pradesh, India. Palaeobotanist, v. 22(3), pp. 79-105.

Prasad, M., 1994, Siwalik (middle- Miocene) leaf impressions from the foot hills of the Himalaya, India. Tert. Res., v. 15, pp. 53-90.

Prasad, M., 2008, Angiospermous fossil leaves from the Siwalik foreland basins and their palaeoclimatic implications. Palaeobotanist, v. 57, pp. 177-215.
Prasad, M., Alok, Chauhan, D. K., Singh, S. K., and Pandey, S. M., 2017, Middle Miocene (Siwalik) plant megafossils from the Sub-Himalayan zone of Uttarakhand and their palaeoclimatic implications. Jour. Palaeontol. Soc. India, v. 62(1), pp. 97-120.

Prasad, M., and Pandey, S. M., 2008, Plant diversity and climate during Siwalik (Miocene-Pliocene) in the Himalayan foot Hills of western Nepal. Palaeontographica, v. 278B, pp. 13-70.

Prasad, M., and Pradhan, U. M. S., 1998, Studies on plant fossils from the Siwalik sediments of far eastern Nepal. Palaeobotanist, v. 48, pp. 99-109.

Prasad, M., and Tripathi, P. P., 2000, Plant mega fossils from the Siwalik sediments of Bhutan and their climatic significance. Biological Mem., v. 26, pp. 6-19.

Prasad, M., Antal, J. S., Tripathi, P. P. and Pandey, V. K., 1999, Further contribution to the Siwalik flora from the Koilabas area, western Nepal. Palaeobotanist, v. 48, pp. 49-95.

Press, J. R., Shrestha, K. K., and Sutton, D. A., 2000, Annotated checklist of the flowering plants of Nepal. The Natural History Museum, London, pp.1-430.

Rugmai, W., Grote, P. J., Chonglakmani, C., Zetter, R., and Ferguson, D. K., 2008, A Late Pleistocene palynoflora from the coastal area of Songkhla Lake, southern Thailand. Sci. Asia, v. 34, pp. 137-145.

Rust, J., Singh, H., Rana, R. S., McCann, T., Singh, L., Anderson, K., Sarkar, N., Nascimbene, P., Stebner, F., Thomas, J. C., Solórzano, M. K., Williams, C. J., Engel, M. S., Sahni, A., and Grimaldi, D., 2010, Biogeographic and evolutionary implications of a diverse paleobiota in amber from the early Eocene of India. Proc. Natl. Acad. Sci. U.S.A., v. 107(43), pp. 18360-18365.

Shi, G. L. and Li, H. M., 2010, A fossil fruit wing of Dipterocarpus from the middle Miocene of Fujian, China and its palaeoclimatic significance. Rev. Palaeobot. Palynol., v. 162, pp. 599-606.

Shukla, A., Mehrotra, R. C., and Guleria, J. S., 2013, Emergence and extinction of Dipterocarpaceae in western India with reference to climate change: Fossil wood evidences. Jour. Earth. Syst. Sci., v. 122(5), pp. 1373-1386.

Songtham, W., Ratanasthien, B., Watanasak, M., Mildenhall, D. C., Singharajwarapan, S., and Kandharosa,W., 2005, Tertiary basin evolution in northern Thailand: a palynological point of view. Nat. Hist. Bull. Siam. Soc., v. 53(1), pp. 17-32.

Srivastava, G., and Mehrotra, R. C., 2010, Tertiary flora of northeast India vis-'a-vis movement of the Indian plate. Geol. Soc. India Mem., v. 75, pp. 123-130.

Srivastava, R., Chandel, R. S., and Singh, S., 2014, Fossil wood of Dipterocarpus from Nagri Formation (Middle Siwalik) of India: palaeoclimatic and phytogeographical significance. Palaeobotanist, v. 63, pp. 41-49.

Valdiya, K. S., 2002, Emergence and evolution of Himalaya: reconstructing history in the light of recent studies. Prog. Phys. Geogr., v. 26(3), pp. 360-399.

Woodward, F. I, Lomas, M. R., and Kelly, C. K., 2004, Global climate and the distribution of plant biomes. Phil. Trans. Royal Soc. London B, v. 359, pp. 1465-1476. 